\title{
OKUN'S LAW OVER THE BUSINESS CYCLE: DOES IT CHANGE IN THE EU COUNTRIES AFTER THE FINANCIAL CRISIS?
}

\section{Marcel Novák, Ľubomír Darmo*}

\begin{abstract}
The relationship between economic growth and unemployment is well known. The growth of gross domestic product leads to a fall in unemployment and, reversely, its fall is associated with a rise in unemployment. The paper deals with the estimation of Okun's coefficient for EU28 countries between years 2001 and 2014. Additionally, two sub-periods are also analysed. These represent the pre-crisis period 2001-2007 and the post-crisis period 2008-2014. The result shows higher Okun's coefficient in the post-crisis period. Unemployment in that period responded to changes in gross domestic product more sensitively than in the pre-crisis period. As a result, in order to decrease unemployment, lower economic growth was necessary in the post-crisis period compared to the pre-crisis one.
\end{abstract}

Keywords: business cycle, unemployment, Okun's law

JEL Classification: E24, E32

\section{Introduction}

The most important factor influencing the level of unemployment is the size of economy, usually measured by GDP. A change in GDP, its growth or decline is associated with an opposite reaction in unemployment. The relationship between economic growth and unemployment is known as Okun's law. The reaction of unemployment to GDP changes is various in different periods. The prevalent view is considered to be proper. At the beginning of a growth period, higher product is produced by increasing productivity or rising working hours of existing workforce. Thus, economic growth has only a modest effect on a decline in unemployment. Further, the ongoing growth requires additional labour. The number of people employed is no longer able to produce increasing level of production. Additional labour comes from the stock of unemployed people, which subsequently reduces the unemployment rate. The situation differs in the crisis period. Firms usually react more sensitively to economic downturn and their reaction is quicker. If production falls, lay-offs are more common than the employment of additional workers when production grows.

The goal of the paper is to examine whether the reaction of unemployment to changes in gross domestic product is the same in the pre-crisis and post-crisis periods. The crisis of 2007/2008 gives the opportunity to estimate Okun's coefficient for the both periods.

\footnotetext{
* Marcel Novák, Faculty of National Economy, University of Economics in Bratislava, Slovakia (marcel.novak@euba.sk);

Lubomír Darmo, Faculty of National Economy, University of Economics in Bratislava, Slovakia (lubomir.darmo@euba.sk).

This paper was supported by the Grant Agency VEGA under its Project No. 1/0975/15

"Macroeconomic and Microeconomic Effects and Impacts of Inflation and Deflation".
} 


\section{Literature Review}

The theoretical background of the relationship between unemployment and economic growth is given in Okun (Okun, 1962) and elaborated in Knotek (Knotek, 2007). The paper outlines a theoretical view of Okun's law and describes its three versions (specifications) the difference, the gap and the dynamic versions. Knotek has analysed the stability of Okun's law over time, i.e. a change in coefficients over a business cycle. He has concluded that Okun's law is not a tight relationship. Okun's coefficient is different in the time of recession and in the time of expansion. Moreover, the weakening of the contemporaneous relationship between output and unemployment has coincided with the stronger relationship between past output growth and current unemployment (Knotek, 2007). The unemployment reaction to the change in product is not immediate, but lagged.

The following literature consists of two types of papers. Firstly, authors analysed papers that deal with a change in Okun's coefficient over a business cycle. Usually, the analysed period was split up to the expansion and recession parts. The second group of papers relates to the research of Okun's law within the EU countries, some papers also include analyses of the crisis and post-crisis (recovery) periods.

Owyang and Sekhposyan (Owyang, Sekhposyan, 2012) have used three specifications of Okun's law to assess the stability of Okun's coefficient over the business cycle, especially during the Great Recession and crises in the 1970s, 1980s and 2000s. They have found a great degree of instability in the historical performance of Okun's law (Owyang, Sekhposyan, 2012). The most important breaks of coefficients were associated with these recessions and appeared around the time when crises arose. Owyang and Vermann (Owyang, Vermann, 2013) have observed the relationship between the change in unemployment and the change in GDP by the use of quarterly data from Q2/1948 to Q1/2013. They differentiate between observations in the periods of expansion and those in the periods of recession. They conclude that the relationship between unemployment and GDP appears to shift over the business cycle (Owyang, Vermann, 2013). The slopes of regression lines are in both periods similar, the difference is in their intercept. The value is lower in expansion times. The following analysis focuses on post-recession recoveries and non-recoveries. The recovery regression line is flatter than the non-recovery line. Thus, changes in GDP relate to smaller changes in the unemployment rate. This conclusion is not surprising and confirms the phenomenon of "jobless recoveries" mentioned later in Levine.

Economic growth does not immediately appear in a decline of the unemployment rate. This relationship is usually lagging. Levine (Levine, 2013) has analysed such situations. For example, the length of time for unemployment to fall was 17 months after the 1991 crisis, 21 months after the 2001 crisis and 12 months after June 2009 (considered as the end of the financial crisis). The fall in unemployment is defined as successive monthly declines (Levine, 2013). The periods of non-successive declines in unemployment are nowadays longer than in the post-war period or after former crises (e.g. oil shocks). As recoveries do not create new jobs, while the economy grows, it is called "jobless recoveries". 
Why does this happen? At the beginning of a recovery period, companies may dispose of underutilized employees. As the economy grows, companies are able to increase their production in order to satisfy increasing demand by their current employees without the necessity to hire additional workers and only by rising productivity. At a certain point in time, the current workers are not able to produce sufficient production to satisfy demand. As long as the growth in GDP exceeds the growth in labour productivity, employment is rising. Companies have to hire additional workers and unemployment starts to fall.

Özel, Sezgin and Topkaya (Özel, Sezgin, Topkaya, 2013) have analysed the relationship between unemployment, economic growth and productivity for the G7 countries between 2000 and 2011. In addition, they have investigated two sub-periods: 2000-2007 and 2008-2011. In other words, the analysed periods represent the pre- and post-crisis periods. Further on, the results for the sub-periods have been mutually compared. They have shown that while productivity and economic growth have significant and strong effect on the reduction of unemployment in the pre-crisis period, this effect of productivity becomes insignificant and small after the crisis, whereas the effect of economic growth as a decreasing effect over unemployment continues and its impact rises (Özel, Sezgin, Topkaya, 2013). This conclusion is in contradiction to Levine and Owyang and Vermann. They have come to the conclusion that the effect of economic growth on the fall in unemployment is smaller in the post-crisis periods, or the periods of recession, than in the pre-crisis or expansion periods, due to the growth in productivity. For higher production, idle workers are used without a necessity to create new jobs.

Doğru (Doğru, 2013) has investigated the relationship between economic growth and unemployment in euro area. The dataset consists of its 17 member countries that adopted the common currency in the period 2000-2012. The panel vector error correction model was used to estimate Okun's coefficient. In addition, Fully Modified Ordinary Least Square (FMOLS) and Dynamic Ordinary Least Square (DOLS) cointegration estimations were also used. By the first estimation, a $1 \%$ increase in unemployment induces a $0.60 \%$ decrease in GDP. According to the FMOLS estimation, a 1\% decrease in real GDP increases the unemployment rate by $0.02 \%$ and a $1 \%$ increase in the unemployment rate implies a $0.03 \%$ decrease in real GDP. The results of the DOLS estimation are very similar to the coefficients of $0.04 \%$ and $0.01 \%$. Gabrisch and Buscher (Gabrisch, Buscher, 2005) have analysed the unemployment - growth dynamics in eight new EU member countries from CEE. They have used panel regressions with instrumental variables - a TSLS approach. The results have showed that unemployment responds to the changes in GDP and not to the changes in institutional environment. In addition, the employment relevant component of aggregate demand is too low to reduce substantially the high level of unemployment (Gabrisch, Buscher, 2005).

Another analysis for transition countries was made by Izyumov and Vahaly (Izyumov, Vahaly, 2002). They have investigated the Okun's law by using the difference version for 25 transition countries. These were divided into reform leaders represented by $10 \mathrm{EU}$ accession countries and reform laggards for the period 1991-2000. Moreover, the time period was divided into two sub-periods of 1991-1994 and 1995-2000. The Okun's law 
holds for the reform leaders in both sub-periods. However, it does not hold for the laggards in the first sub-period. The Okun's law holds only in the second sub-period, but only after omitting countries affected by war. The analysis has showed that the labour market of EU candidates might converge. A similar analysis related to the transition countries was made by Cevik, Dibooglu and Barişik (Cevik, Dibooglu, Barişik, 2013). Bod’a, Medved'ová and Považanová (Bod’a, Medved'ová, Považanová, 2015) have analysed the asymmetry in Okun's law in the Visegrad Group countries. They used the gap version of Okun's law for quarterly data since Q1/1998 to Q2/2014. The asymmetry in Okun's coefficient was found for the Slovak Republic. An important conclusion of the paper is that Okun's law holds if GDP is over its potential level. However, if GDP decreases below this level, unemployment seems to be inert. Thus, unemployment does not react to the change in GDP.

Mielcová (Mielcová, 2011) have compared estimations of Okun's law for the Czech Republic (representing a transition economy), the USA (a leading economy) and France (a Western European type of economy). The period 1996-2009 and the difference and dynamic versions of Okun's law were used. The author found the strongest relationship between the unemployment rate and GDP growth in the transition country. In the Czech Republic, a 1 p.p. decrease in the unemployment rate is bound with a $10.1 \%$ increase in real GDP (Mielcová, 2011), while it is only $2.7 \%$ in France and $1.8 \%$ in the USA. Durech, Minea, Mustea and Slusna (Durech, Minea, Mustea, Slusna, 2014) observed regional heterogeneities in the validity of Okun's law in the Slovak and Czech regions. Factors causing the regional differences were identified, such as the level of unemployment and regional GDP, investments, infrastructure and R\&D expenditures. The comparison of the Czech Republic and Belgium as to the relationship between employment and GDP per capita is given in Maitah, Toth and Kuzmenko (Maitah, Toth, Kuzmenko, 2015). They have used the ARIMA model to verify the inverted version of Okun's law. The result shows that a 2\% GDP per capita growth induces an increase in employment of 1\%. D'Apice (D'Apice, 2014) has analysed the Slovak labour market. His paper is aimed at answering the question whether Okun's law holds in crisis periods. The analysed sample covers the Visegrad countries in the period from 1997 to 2012. The growth rate of 3.6\% is estimated as sufficient to keep unemployment stable in the Czech Republic, while it is $3.9 \%$ for Poland and $4.7 \%$ for Slovakia. Relatively high growth is needed for the unemployment rate to fall (D'Apice, 2014). The common feature of these countries is the very high level of unemployment in the 1990s (in the transition period). The Slovak labour market is very sensitive to GDP changes (the estimated value of Okun's coefficient is -0.30 ). In comparison with other Visegrad countries, and Germany as a benchmark economy, unemployment in Slovakia is very sensitive to cyclical developments. However, the estimation of Okun's coefficient has not changed owing to the financial crisis of 2007. However, Okun's law did hold during the latest recession (D'Apice, 2014). Moreover, the estimation was similar to the previous post crises developments (e.g. "dot.com bubble").

Caraiani (Caraiani, 2012) has analysed the Romanian economy. The study's purpose has been to analyse whether Okun's coefficient is asymmetric and whether this relationship 
is correlated with a business cycle. The author has also been interested in the dynamics of unemployment during a post-crisis recovery. Okun's coefficient was estimated by the combination of two approaches - a gap version and a Markov's switching approach using a maximum likelihood model. The monthly data since January 1991 to December 2009 were used. The result showed that Okun's coefficient had two stages and there existed its strong and weak alternatives. It means that there is a phase of a stronger reaction of unemployment to changes in product, and a stage when the reaction is modest or weak. The important finding is that the changes from the weak to strong relationship and vice versa are associated with a business cycle. The recession that started in 2008 changed Okun's coefficient to the strong phase. This result might explain the sharp increase in the unemployment rate after 2008 and the slow decline in period 1999-2007 associated with the growth of the Romanian economy. To conclude, the relationship between unemployment and GDP growth seems to be stronger in the time of recessions.

\section{Data and Methodology}

In order to analyse the relationship between unemployment and economic performance, the paper captures the period from 2001 to 2014, thus 14 time intervals. The economic performance is expressed by the use of GDP. According to Hronová et al. (Hronová, Fisher, Hindls, Sixta, 2009), GDP is the indicator, which is used to measure and compare economic development of countries, standard of living and growth of national economies. The dataset consists of 28 cross-sectional units represented by the EU28 countries. The data source is Eurostat.

The description of data used in the paper is given in the following table.

Table 1 | Characteristics of GDP and Unemployment Variables

\begin{tabular}{|l|l|c|}
\hline Variable & \multicolumn{1}{|c|}{ Description } & Source \\
\hline Gross Domestic Product & Chain-linked volumes to 2010 (€ millions) & Eurostat \\
\hline Unemployment & Unemployment rate (\%) & Eurostat \\
\hline
\end{tabular}

Source: Authors.

The development of GDP growth and unemployment rate for EU28 in period 2001-2014 shows the moderate relation between these two variables (see Figure in Appendix 1). While the relationship seems to be relevant in the pre-crisis period, the relationship after the financial crisis is not obvious. Effort to explain the relationship between GDP and unemployment declares the importance and relevance of further research.

Following the difference version of Okun's law (Knotek, 2007), GDP growth ( $g G D P$ ) and the first difference of the unemployment rate $\left(d_{-} U R\right)$ was calculated. The annual GDP and unemployment rate data were used. The descriptive statistics of these variables are shown in Table 2. 
Table 2 | Summary Statistics of Variables

\begin{tabular}{|l|c|c|c|c|c|c|c|}
\hline Variable & $\begin{array}{c}\text { Obser- } \\
\text { vations }\end{array}$ & Mean & Median & Minimum & Maximum & Std.dev. & c.v. \\
\hline $\boldsymbol{g G D P}$ & 392 & 2.044771 & 2.281028 & -14.814190 & 11.902350 & 3.640682 & 1.7804839760 \\
\hline $\boldsymbol{d}$ U $\boldsymbol{R}$ & 392 & 0.099490 & 0.000000 & -4.500000 & 9.800000 & 1.590107 & 15.9825811639 \\
\hline
\end{tabular}

Source: EViews 8, authors.

For further investigation, the stationarity of the used series was controlled by using the Levin, Lin and Chu test of the common unit root and the Im, Pesaran and Shin test of the unit root for each unit, i.e. per country. Stationarity has been tested for $g G D P$ at the level and for the UR at the $1^{\text {st }}$ difference, i.e. $d \_U R$. The $1^{\text {st }}$ difference was used owing to the use of the difference version of Okun's law in further analysis. The results of both methods are given in Table 3 and confirm that all variables used in the analysis are stable.

Table 3 | Results of Panel Unit Root Tests

\begin{tabular}{|l|c|c|c|c|}
\hline & \multicolumn{2}{|c|}{ gGDP } & \multicolumn{2}{c|}{ d_UR } \\
\hline Method & Statistic & prob. & statistic & prob. \\
\hline Levin, Lin and Chu test & -7.95625 & 0.0000 & -7.08145 & 0.0000 \\
\hline Im, Pesaran and Shin W-stat & -4.13430 & 0.0000 & -5.08280 & 0.0000 \\
\hline
\end{tabular}

Source: EViews, authors.

Given by Knotek (Knotek, 2007), the difference version approach to Okun's coefficient estimation was applied. The difference version is expressed as:

$$
\Delta U R_{t}=a+b \quad g G D P_{t}
$$

The equation was adjusted by the consideration for the use of panel data. We calculated GDP growth and used the first difference of the unemployment rate. Following this adjustment, the equation reads as:

$$
d_{-} U R_{i t}=\alpha_{i}+\beta * g G D P_{i t}+u_{i t}
$$

where: $d_{-} U R$ is the first difference of the unemployment rate (a year-on-year change in the unemployment rate); $g G D P$ is real GDP growth; $\alpha$ is the constant (intercept); $\beta$ is the coefficient representing the relationship between growth and unemployment, thus Okun's coefficient; $u$ is the error term; $i$ is the index for a county; and $t$ is the index for a time period.

The estimation of Okun's coefficient has some particularities. Firstly, the unemployment rate, or its change, is affected not only by the volume of output and its growth, but also 
by other factors such as labour productivity, labour cost or wages, qualification, etc. As a result, Okun's coefficient estimated by the simple regression model by the OLS might be biased due to omitted variables. Secondly, GDP in the model is considered as an exogenous variable, which is not a reliable hypothesis. Further on, the relation between GDP growth and unemployment is a simultaneous causality. GDP growth affects a change in the unemployment rate. However, at the same time, the change in the unemployment rate may influence the volume of GDP. In this case, due to endogeneity, the OLS would give a biased estimate. Therefore, the instrumental variables technique must be used. Moreover, the response of the change in unemployment is not immediate, as given in the simple regression model of the Okun's coefficient estimation, but it takes some time. This reflects the dynamic version of Okun's law. Therefore, the lagged dependent variable $\left(d_{-} U R_{i, t-1}\right)$ is used on the right side of the equation as a regressor. To obtain an unbiased and consistent estimation, the dynamic panel data/GMM estimation technique is proper to be used. With this adjustment, the equation is as follows:

$$
d_{-} U R_{i t}=\alpha_{i}+\beta * g G D P_{i t}+d_{-} U R_{i, t-1}+u_{i t}
$$

We did the Sargan over-identification test and the Wald (joint) test for parameters using the dynamic panel model estimation. The AR test for the autocorrelation of residuals has also been taken.

Firstly, we estimated Okun's coefficient for the period 2001-2014. Consequently, coefficients for sub-periods were estimated and compared to each other. The breaking point of the 2001-2014 period was the outbreak of the financial crisis and the sub-periods were 2001-2007 (the pre-crisis period) and 2008-2014 (the post-crisis period). This period was selected due to missing data on the unemployment rate for some countries until 2000. Consequently, the change in the unemployment rate might be calculated only from 2001. As a result, both periods had the same length of 7 years and the same number of observations.

\section{Results}

The unemployment rate differs across the EU28 countries. The highest unemployment rate in 2014 was observed in Greece with unemployment of $26.5 \%$. To the contrary, it was only 5\% in Germany. Twelve EU countries reported the unemployment rate of above 10\%. Moreover, in Greece and Spain it exceeded 20\% (26.5\% and 24.5\%, respectively). On the lower end of the range were Germany, Austria and Malta. Only these countries reached unemployment lower than $6 \%$.

How did unemployment change over time in the sub-periods defined as precrisis and post-crisis? Due to the lack of data for some countries until 2000, the comparison of unemployment in the pre-crisis sub-period started with data for 2001. This enabled us to compare the two time periods of the same length of seven years before and after the crisis. The confrontation of the unemployment rate between 2001 and 2007 showed that in eleven countries the unemployment rate was higher in 2007 than in 2001, one country had the same unemployment rate, and unemployment in 16 countries improved and started to fall. Furthermore, the fall in the unemployment rate in these countries was much larger 
than its growth in the countries with increasing unemployment. The GDP growth data for the same period might assume Okun's law was correct. In 2007, 20 countries reached higher GDP growth than in 2001. One country had the identical growth and it decreased in only seven countries. The Figures in Appendix 2 show the unemployment rate and GDP growth in years 2001 and 2007.

The second sub-period started with the 2007/2008 financial crisis. When comparing 2008 and 2014, unemployment fell only in three countries (Germany, Hungary and Malta) and rose in 25 countries. Apparently, the situation changed completely in comparison with the first sub-period. If Okun's law also held in the post-crisis period, the assumption would be that only a few countries improved their economic growth. The data showed that 15 countries had higher GDP growth in 2014 than in 2008 (or had a positive growth instead of a negative one in 2008) and ten countries worsened their performance (see Appendix 3). Such a brief view of unemployment and GDP data is obviously not sufficient to make a conclusion about the validity of Okun's law. Therefore, the analysis continued with the estimation of Okun's coefficients for the whole period and for both sub-periods.

Okun's coefficients for the period 2001-2014 and for the both sub-periods are given in Appendix 4. The variable GDP growth is negative and significant in the entire period as well as in the pre- and post-crisis periods. It confirms the negative relationship between unemployment and economic growth. The result for the entire period shows that the growth of $1 \%$ implies the decline in the unemployment rate of 0.29 p.p.

In addition, two estimates were run to identify the difference between Okun's coefficients in the pre- and post-crisis periods (Appendix 5 and 6).

The result for the pre-crisis sub-period refers to the coefficient of -0.15 for the GDP growth variable. It means a 0.15 p.p. decrease in the unemployment rate in the case of a $1 \%$ GDP growth. The coefficient gGDP in the post-crisis period is -0.35 . The $1 \%$ growth in GDP in the period 2008-2014 induces a decrease in the unemployment rate of 0.35 p.p. In the post-crisis period, Okun's coefficient is more than twice higher. The effect of GDP growth on unemployment after the financial crisis is stronger. This result is the same as in Özel, Sezgin and Topkaya (Özel, Sezgin, Topkaya, 2013) and Caraiani (Caraiani, 2012), but contrary to Levine (Levine, 2013) and Owyang and Vermann (Owyang, Vermann, 2013). Moreover, the result contradicts the common view given in the introduction.

Following the results, the constant was expected to have a positive sign. It means that the unemployment rate is rising when economy stagnates and there is no previous change in the unemployment rate. The constant was similar in the both sub-periods. The lagged variables of $d_{-} U R$ had a positive sign in the both sub-periods. However, the value was higher in the period 2008-2014. The positive sign means that the growth in the unemployment rate in the previous period induces the current increase in the unemployment rate. This result indicates the dependence of current changes in the unemployment rate on its previous changes. The growth in the unemployment rate in the past implies its growth in the present, and vice versa. 


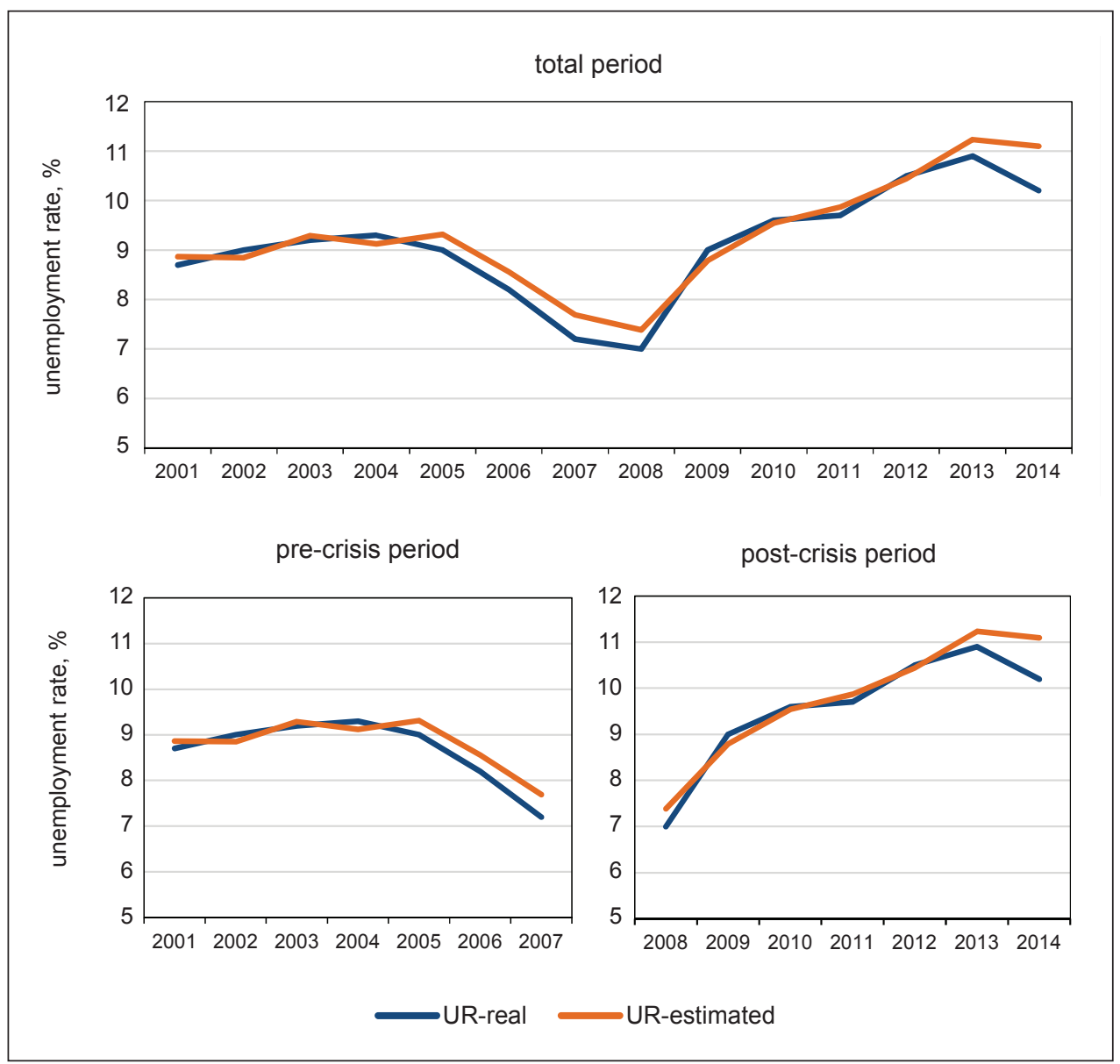

Source: Eurostat, authors' estimations from Okun's low results.

The relevance of our estimates might be verified on the data for EU28 for which the panel data were used as well as for the Slovak Republic, as an example of EU28 representative. Figures $1 \mathrm{a}$ and $1 \mathrm{~b}$ present the real and the estimated unemployment rate. The real unemployment rate shows the official Eurostat data on the unemployment rate. The estimated unemployment rate is calculated on the basis of estimation results for the Okun's law. The real unemployment rate and the estimated unemployment rate have almost similar trajectory. Deviations between the real and the estimated unemployment rate might be caused by variables, which are not included in the estimates. The similarity of the real and estimated unemployment rate is seen in the total study period (with the regard to the estimated coefficients for the total period), as well as for the pre-crisis and the post-crisis periods (with the regard to the estimated coefficients for the pre-crisis period and the estimated coefficients for the post-crisis period). Both Figures (1.1a and 1.2) 
show that at the end of analysed post-crises period, estimated unemployment rate is higher than real unemployment rate. Such finding is common for the Slovak Republic, as well as for EU28. We assume that the gap in real and estimated unemployment rate is affected by labour market reforms taken after financial crisis, e.g. young employment, training subsidies or reducing tax wedge. Similar results for the Slovak Republic were presented by the Governor of National Bank of Slovakia. On the basis of the estimated relationship between GDP and employment growth rates, there is evidence that actual employment growth has been stronger than estimated employment growth. For the period 2013-2017 the cumulative difference in headcount employment was around 70,000, which to some extent demonstrates the impact of the labour market policy measures implemented in recent years (Makúch, 2017). In spite of National Bank of Slovakia he focuses on the analysis of employment growth, and the results correspond to our findings.

Figure 1.2 | Comparison of Real and Estimated Unemployment Rate for the Slovak Republic

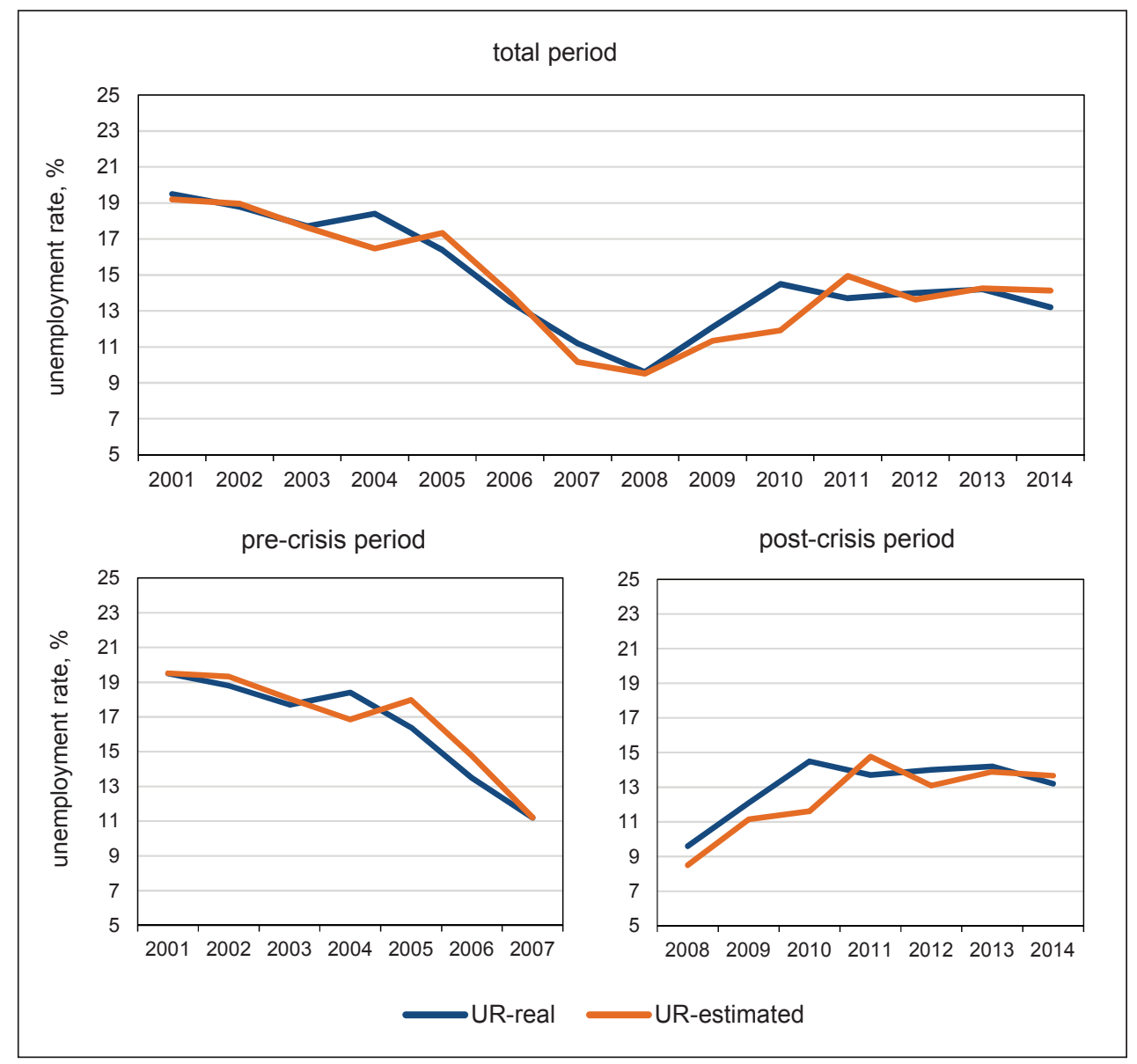

Source: Eurostat, authors' estimations from Okun's low results. 
The result implies the change in Okun's coefficient over a business cycle. It shows a stronger relationship between unemployment and GDP growth in the post-crisis period. To conclude the analysis, we calculated the size of economic growth necessary to lower the unemployment rate by 1 p.p. To calculate this growth, we assumed that the previous change in the unemployment rate was zero. Considering Okun's coefficient and the constant, the economic growth necessary for a decline in unemployment of 1 p.p. is given in Table 5 .

Table 5 | Growth Necessary to Reduce the Unemployment Rate by $1 \%$

\begin{tabular}{|l|c|c|c|}
\hline Period & 2001-2014 & 2001-2007 & 2008-2014 \\
\hline Growth (\%) & 5.51 & 8.74 & 3.59 \\
\hline
\end{tabular}

Source: Authors.

The growth has to be of $5.51 \%$ for the whole period, $8.74 \%$ for the pre-crisis period and $3.59 \%$ for the post-crisis one. As observed, the economic growth necessary for declining unemployment by 1 p.p. is very high. If governments want to reduce unemployment, the EU economies have to perform well and authorities have to support the economic boost. However, this growth was not accompanied by a decline in unemployment. Nowadays, after the financial crisis, EU countries are successful in combating unemployment. The analysis proved this situation. Under the assumption of the same GDP growth, the unemployment rate would decrease more in the post-crisis period than in the pre-crisis period.

To complete the analysis, we may confirm the stronger relationship between GDP growth and unemployment during the crisis and in the post-crisis period (20082014) than in the period of economic boom or expansion (2001-2007), which was interrupted by the $2007 / 2008$ financial crisis. The relationship between unemployment and economic growth was tighter in the period 2008-2014 (the crisis and post-crisis periods) than in the pre-crisis period 2001-2007. The reaction of unemployment to the changes in GDP growth was stronger in the post-crisis period. Lower GDP growth was necessary to reduce the unemployment rate in the crisis and post-crisis periods than in the pre-crisis period. This result may be explained as follows. The unemployment rate in the EU countries after the financial crisis achieved an unsustainable level. Many countries took various measures and actions to reduce the unemployment rate. These measures were associated with grants and subsidies for employers to employ workers from disadvantaged groups or to create part-time jobs. Other measures included the creation of new jobs by increasing public orders in the area of infrastructure (construction and reconstruction of highways and railways). All these measures increased employment or decreased unemployment. In addition, we have to consider the cost of implementation measures, which helped to decrease unemployment. It is the deficit and debt the EU countries have to face. 


\section{Conclusion}

The paper analyses a relationship between unemployment and output growth for the EU28 countries in the period from 2001 to 2014. Additionally, two sub-periods of 20012007 and 2008-2014 were examined and compared with each other. The result shows the stronger relationship between the change in the unemployment rate and GDP growth in the post-crisis period 2008-2014. Despite the strong relation, economic growth needs to be relatively high in order to induce a fall in the unemployment rate. The GDP growth in the EU countries does not have the expected effect of reducing the unemployment rate in the analysed period. The situation becomes better after the financial crisis. In this period, Okun's coefficient is higher than in the pre-crisis period. It means that economic growth in the post-crisis period decreases the unemployment rate more than in the period before the financial crisis of 2008 .

The comparison of the unemployment rate between 2001 and 2007 has showed that the unemployment rate was higher in eleven countries, the same in one country and fell in sixteen countries. To the contrary, twenty countries achieved higher economic growth in 2007 than in 2001. One country had the identical growth, while it decreased in seven countries. Therefore, the fall in the unemployment rate in these countries was much larger than its rise in the countries with increasing unemployment. When comparing 2008 and 2014, unemployment fell only in three countries and rose in twenty-five countries. GDP growth was higher in fifteen countries and ten countries worsened their performance. As we assumed, the situation changed completely after the financial crisis.

The result implies the change in Okun's coefficient over a business cycle. It shows a stronger relationship between unemployment and GDP growth in the post-crisis period. Okun's coefficient is more than twice higher in the post crisis period. The effect of GDP growth on unemployment after the financial crisis is stronger. These results are similar to those in Özel, Sezgin and Topkaya (Özel, Sezgin, opkaya, 2013) and Caraiani (Caraiani, 2012), but contrary to Levine (Levine, 2013) and Owyang and Vermann (Owyang, Vermann, 2013). Okun's law held during the latest recession (D’Apice, 2014). According to Bod’a, Medved’ová and Považanová (Bod’a, Medved’ová, Považanová, 2015), Okun's law holds only under condition that real GDP is over its potential level. Their conclusions are contrary to our paper results, as we assumed that the post-crisis period is linked to the low real GDP level. Our findings correspond with the results of Mielcová (Mielcová, 2011), who found a strong relationship between the unemployment rate and GDP growth in a transition country. Similarly, Okun's law holds in transition countries studied by Izyumov and Vahaly (Izyumov, Vahaly, 2002).

The EU member countries' governments have to support economic growth in order to reduce unemployment. However, the paper unveiled that GDP growth was not adequately accompanied with a decline in unemployment in the pre-crisis period. After the financial crisis, countries have been more successful in their economic policies focussed on reducing unemployment. 


\section{Appendices}

Appendix 1 | Unemployment Rate and GDP Growth for EU28 in Period 2001-2014

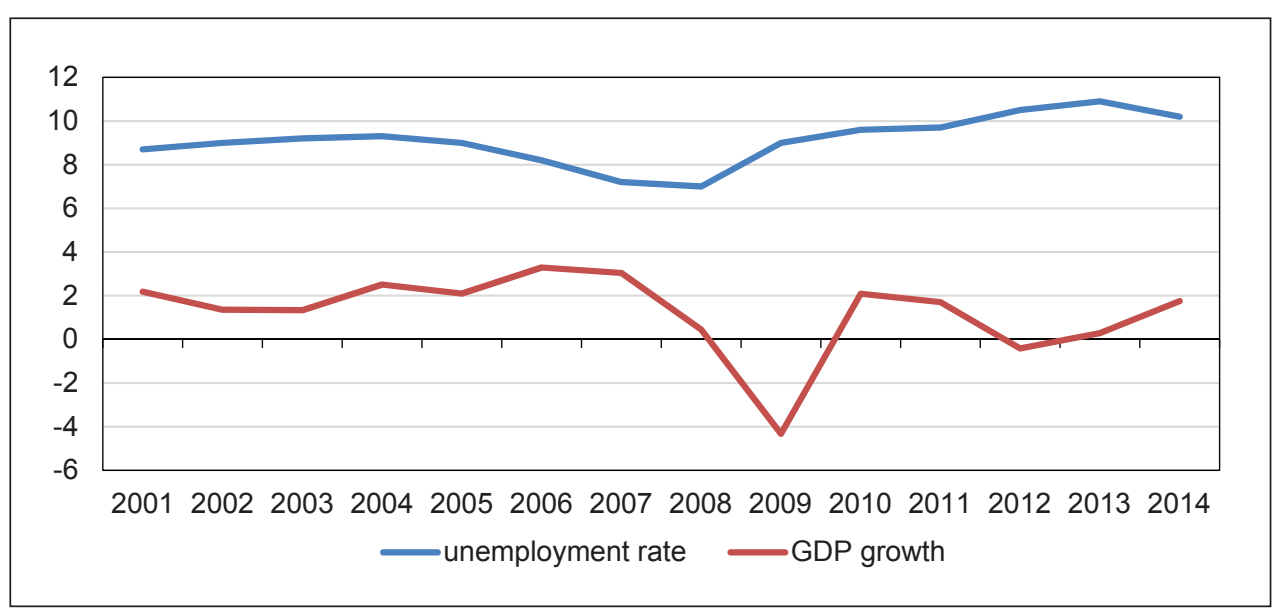

Source: Eurostat. 
Appendix 2 | Unemployment Rate and GDP Growth for EU28 in 2001 and 2007

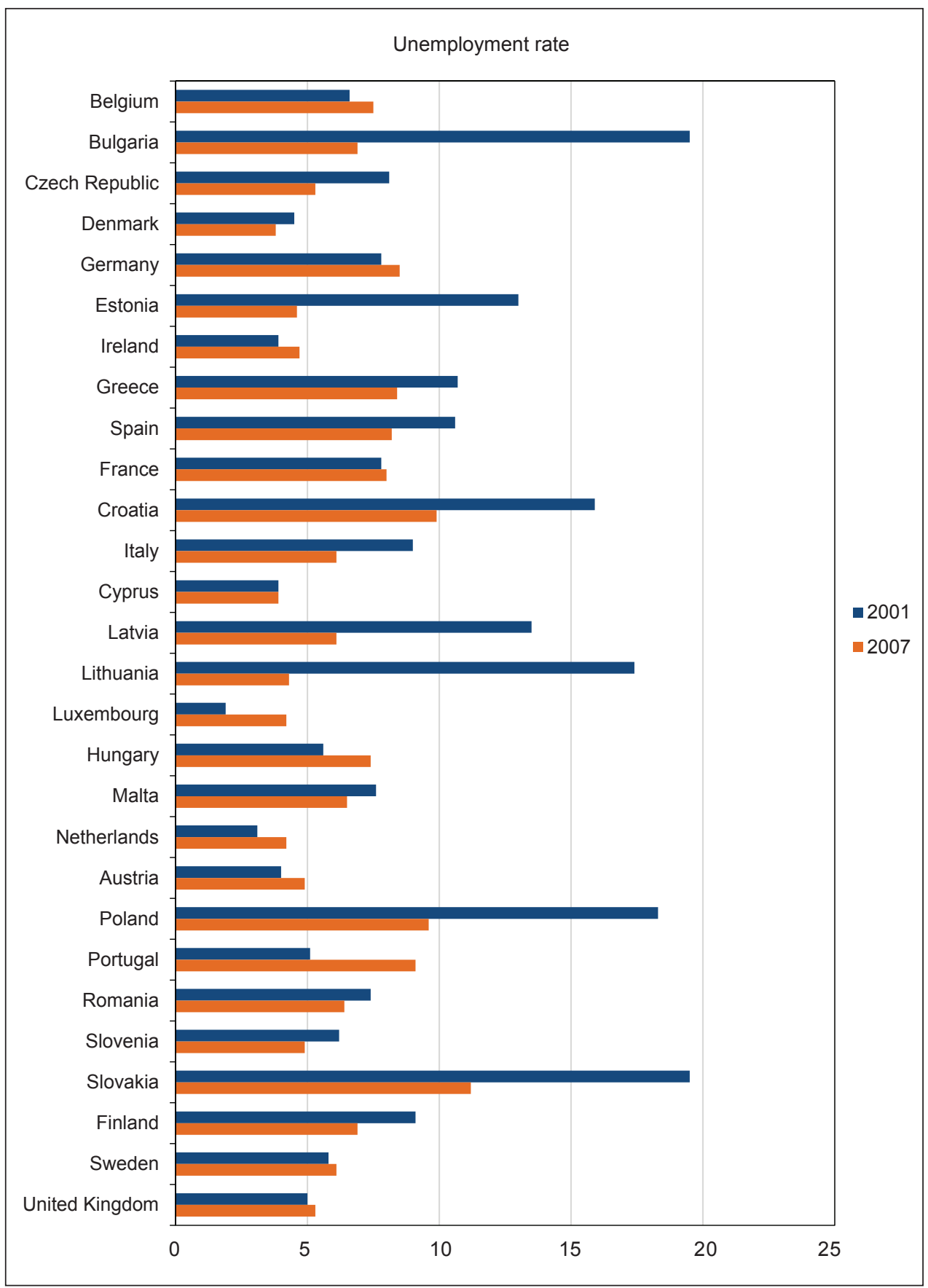

Source: Eurostat. 


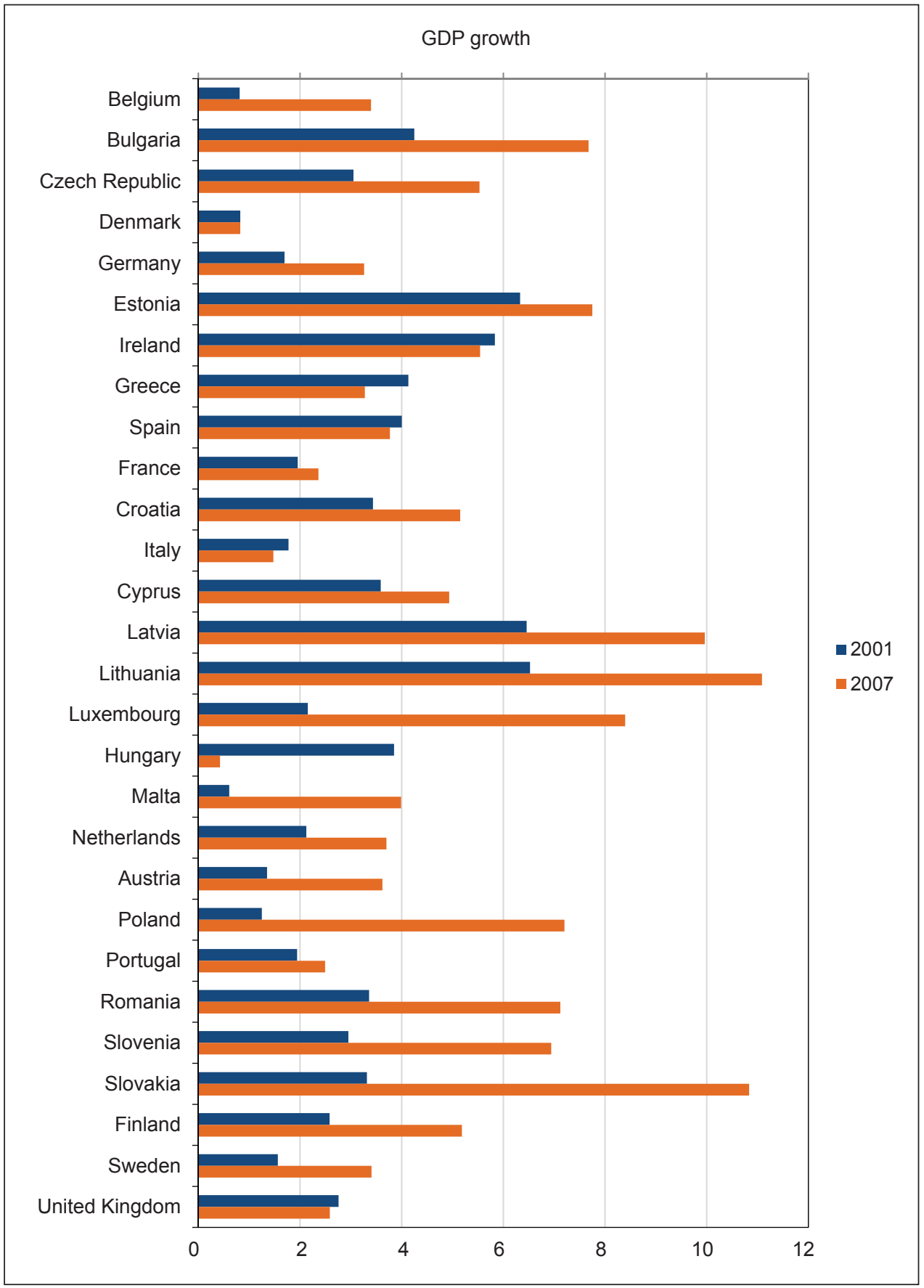

Source: Eurostat. 
Appendix 3 | Unemployment Rate and GDP Growth for EU28 in 2008 and 2014

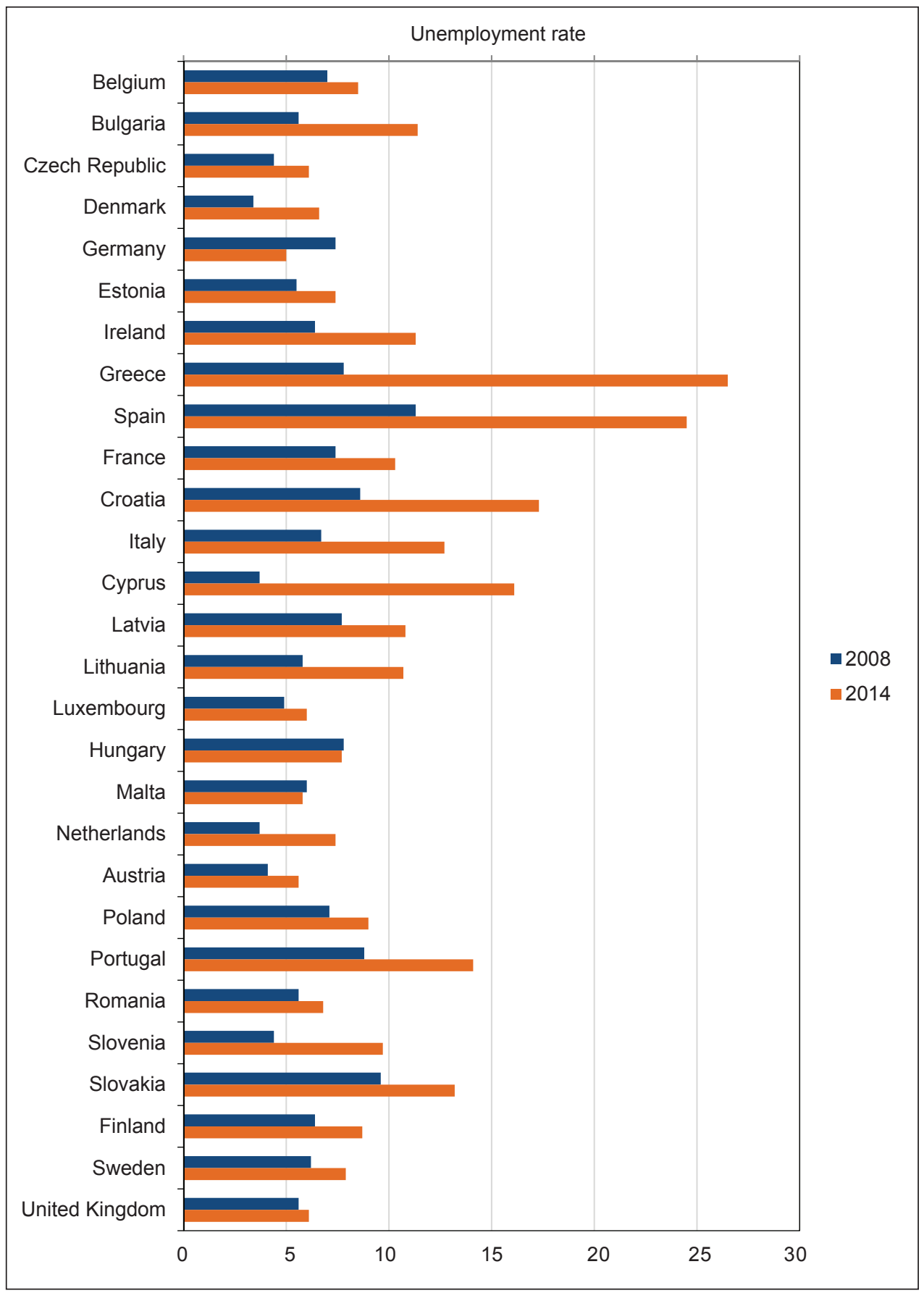

Source: Eurostat. 


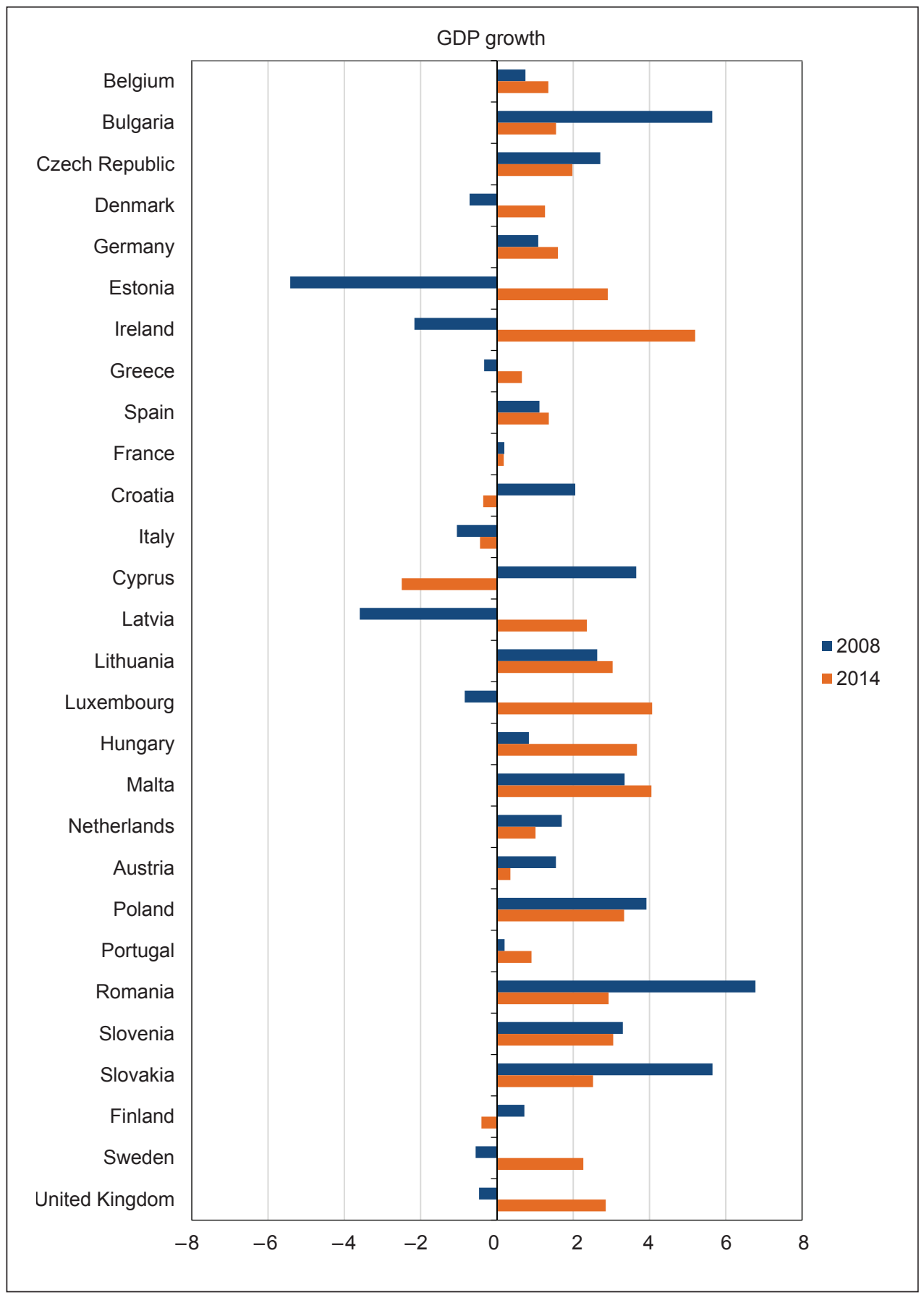

Source: Eurostat. 


\begin{tabular}{|c|c|c|c|c|}
\hline & coefficient & std. error & $z$ & $p$-value \\
\hline const & 0.593088 & 0.0991351 & 5.983 & $2.20 \mathrm{e}-09 * * *$ \\
\hline$g G D P_{i t}$ & -0.289186 & 0.0309197 & -9.353 & $8.53 e-021 * * *$ \\
\hline $\boldsymbol{d}_{-} \boldsymbol{U} \boldsymbol{R}_{i, t-1}$ & 0.277692 & 0.0823639 & 3.372 & $0.0007^{* * *}$ \\
\hline \multicolumn{5}{|c|}{$\begin{array}{l}\text { - number of instruments: } 92 \\
\text { - test for AR(1) errors: } z=-2.70992[0.0067] \text {; test for } A R(2): z=-1.05364[0.2920] \\
\text { - Sargan over-identification test: } X^{2}(89)=25.0352[1.0000] \\
\text { - Wald (joint) test: } X^{2}(2)=200.908[0.0000]\end{array}$} \\
\hline
\end{tabular}

Note: ${ }^{* *},{ }^{* *},{ }^{*}$ statistical significance at the $1 \%, 5 \%$ and $10 \%$ level

Source: EViews, Gretl, authors.

\section{Appendix 5 | Estimation Result of Okun's Law (2001-2007)}

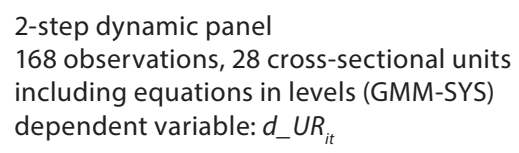

\begin{tabular}{|l|c|c|c|c|}
\hline & coefficient & std. error & $\boldsymbol{Z}$ & $\boldsymbol{p}$-value \\
\hline Const & 0.305283 & 0.1017660 & 3.000 & $0.0027^{* * *}$ \\
\hline $\boldsymbol{g G D P}_{i \boldsymbol{t}}$ & -0.149274 & 0.0350789 & -4.255 & $2.09 \mathrm{e}-05^{* * *}$ \\
\hline $\boldsymbol{d}_{-} \boldsymbol{U} \boldsymbol{R}_{i, t-\mathbf{1}}$ & 0.336477 & 0.1413330 & 2.381 & $0.173^{* *}$ \\
\hline
\end{tabular}

- number of instruments: 22

- test for AR(1) errors: $z=-2.27959$ [0.0226]; test for $A R(2): z=0.0919926$ [0.9267]

- Sargan over-identification test: $X^{2}(19)=21.9363[0.2874]$

- Wald (joint) test: $X^{2}(2)=45.6443[0.0000]$

Note: ${ }^{* * *}, * *{ }^{*}$ statistical significance at the $1 \%, 5 \%$ and $10 \%$ level

Source: EViews, Gretl, authors. 


\begin{tabular}{|c|c|c|c|c|}
\hline \multicolumn{5}{|c|}{$\begin{array}{l}\text { 2-step dynamic panel } \\
168 \text { observations, } 28 \text { cross-sectional units } \\
\text { including equations in levels (GMM-SYS) } \\
\text { dependent variable: } d_{-} U R_{i t}\end{array}$} \\
\hline & coefficient & std. error & $z$ & $p$-value \\
\hline Const & 0.273374 & 0.0947807 & 2.884 & $0.0039 * * *$ \\
\hline$g G D P_{i t}$ & -0.354901 & 0.0420892 & -8.432 & $3.39 \mathrm{e}-017^{* * *}$ \\
\hline $\boldsymbol{d}_{-} \boldsymbol{U} \boldsymbol{R}_{i, t-\mathbf{1}}$ & 0.418764 & 0.1022740 & 4.095 & $4.23 e-05^{* * *}$ \\
\hline \multicolumn{5}{|c|}{$\begin{array}{l}\text { - number of instruments: } 22 \\
\text { - test for } A R(1) \text { errors: } z=-2.53155[0.0114] \text {; test for } A R(2): z=-1.32881[0.1839] \\
\text { - Sargan over-identification test: } X^{2}(19)=18.6605[0.4788] \\
\text { - Wald (joint) test: } \mathrm{X}^{2}(2)=133.059[0.0000]\end{array}$} \\
\hline
\end{tabular}

Note: ${ }^{* *}, * * * *$ statistical significance at the $1 \%, 5 \%$ and $10 \%$ level

Source: Eviews, Gretl, authors.

\section{References}

Bod’a, M., Medved’ová, P., Považanová, M. (2015). (A)symetria v Okunovom zákone v štátoch Vyšehradskej skupiny. Politická Ekonomie, 63(6), 741-758, https://doi.org/10.18267/j. polek.1024

Caraiani, P. (2012). Asymmetry in the Okun Coefficient in Romanian Economy. Ekonomie, 15(4), 49-55.

D'Apice, P. (2014). The Slovak Labour Market in the Wake of the Crisis: Did Okun's Law Hold? ECFIN Country Focus, 11(4), 8.

Doğru, B. (2013). The Link between Unemployment Rate and Real Output in Eurozone:

A Panel Correction Approach. Procedia - Social and Behavioral Science, 99(2013), 94-103, https://doi.org/10.1016/j.sbspro.2013.10.475

Durech, R., Minea, A., Mustea, L., Slusna, L. (2014). Regional Evidence on Okun's Law in Czech Republic and Slovakia. Economic Modelling, 42, 57-65, https://doi.org/10.1016/j. econmod.2014.05.039

Gabrisch, H., Buscher, H. (2005). The Unemployment-Growth Relationship in Transition Countries. IWH Discussion Papers No. 5/2005, https://doi.org/10.2139/ssrn.2031485

Hronová, S., Fisher, J., Hindls, R., Sixta, J. (2009). Národní účetnictví. Nástroj popisu globální ekonomiky. Praha: C. H. Beck. ISBN 978-80-7400-153-6.

Izyumov, A., Vahaly, J. (2002). The Unemployment-Output Trade off in Transition Economies: Does Okun's Law Apply? Economics of Planning, 35(4), 317-331.

Knotek, E. S. (2007). How Useful Is Okun's Law? Federal Reserve Bank of Kansas City, Economic Review, Fourth Quarter, 73-103.

Levine, L. (2013). Economic Growth and the Unemployment Rate. CRS Report for Congress. Congressional Research Service, 7-5700, 10. 
Maitah, M., Toth, D., Kuzmenko, E. (2015). Exploring the Relationship between Economic Growth and Employment in the Czech Republic and Belgium. Review of European Studies, (7)11, 115-124, https://doi.org/10.5539/res.v7n11p115

Makúch, J. (2017). Structural Reforms - Past and Present (Never-ending Story ...)." In: Conference on European Economic Integration (CEII) 2017. A Modern Take on Structural Reforms - Past and Future Challenges for CESEE and Europe at Large. Oesterreichische Nationalbank; November 20-21, 2017; Vienna.

Mielcová, E. (2011). Economic Growth and Unemployment Rate of the Transition Country the Case of the Czech Republic 1996-2009. E+M: Ekonomie a Management, 1, 29-37.

Owyang, M. T., Sekhposyan, T. (2012). Okun's Law over the Business Cycle: Was the Great Recession All That Different? Federal Reserve Bank of St. Louis Review, 94(5), 399-418, https://doi.org/10.20955/r.94.399-418

Owyang, M. T., Vermann, K. E. (2013). Okun's Law in Recession and Recovery. Economic SYNOPSES Short Essays and Reports on the Economic Issue of the Day. Federal Reserve Bank of St. Louis. No. 23, 2 p, https://doi.org/10.20955/es.2013.23

Okun, A. M. (1962). Potential GNP: Its Measurement and Significance. American Statistical Association, Proceedings of the Business and Economics Statistics Section, 98-103. Washington D.C.: American Statistical Association.

Özel, H. A., Sezgin, F. H., Topkaya, Ö. (2013). Investigation of Economic Growth and Unemployment Relationship for G7 Countries Using Panel Regression Analysis. Journal of Business and Social Science, 4(6), 9. 